medRxiv preprint doi: https://doi.org/10.1101/2020.03.25.20041418; this version posted March 30, 2020. The copyright holder for this preprint (which was not certified by peer review) is the author/funder, who has granted medRxiv a license to display the preprint in All rights reserved. No reuse allowed without permission.

\title{
Disruption of the topological associated domain at Xp21.2 is related to gonadal dysgenesis:
}

\section{A general mechanism of pathogenesis}

Ana Paula dos Santos ${ }^{1,2^{*}}$, Jakob A. Meinel ${ }^{3^{*}}$, Cristiane dos Santos Cruz Piveta ${ }^{2}$, Juliana Gabriel Ribeiro de Andrade ${ }^{4,5}$, Helena Fabbri-Scallet ${ }^{2}$, Vera Lúcia Gil-da-Silva-Lopes ${ }^{1}$, Gil GuerraJúnior $^{4,5}$, Axel Künstner ${ }^{6,7}$, Frank J. Kaiser ${ }^{8,9}$, Paul-Martin Holterhus ${ }^{10}$, Olaf Hiort ${ }^{3}$, Hauke Busch $^{6,7}$, Andréa Trevas Maciel-Guerra ${ }^{1,4}$, Maricilda Palandi de Mello ${ }^{2,4}$, Ralf Werner ${ }^{3,11}$

${ }^{1}$ Department of Medical Genetics and Genomic Medicine, State University of Campinas (UNICAMP), Campinas, São Paulo, Brazil; ${ }^{2}$ Molecular Biology and Genetic Engineering Center, State University of Campinas (UNICAMP), Campinas, São Paulo, Brazil; ${ }^{3}$ Department of Pediatrics and Adolescent Medicine, Division of Paediatric Endocrinology and Diabetes, University of Lübeck, Lübeck, Germany; ${ }^{4}$ Interdisciplinary Group for the Study of Sex Determination and Differentiation (GIEDDS), State University of Campinas (UNICAMP), Campinas, São Paulo, Brazil; ${ }^{5}$ Department of Pediatrics, State University of Campinas (UNICAMP), Campinas, São Paulo, Brazil; ${ }^{6}$ Group of Medical Systems Biology, Lübeck Institute of Experimental Dermatology, University of Lübeck, Germany; ${ }^{7}$ Institute for Cardiogenetics, University of Lübeck, Lübeck, Germany; ${ }^{8}$ Institute of Human Genetics, University Duisburg-Essen, University Hospital Essen, Essen, Germany; ${ }^{9}$ DZHK e.V. (German Center for Cardiovascular Research), Partner Site Hamburg/Kiel/Lübeck, Lübeck, Germany ${ }^{10}$ University Medical Center for Pediatric Endocrinology and Diabetes, Department of Pediatrics and Adolescent Medicine I, University Hospital Schleswig-Holstein - Campus Kiel, Kiel, Germany; ${ }^{11}$ Institute of Molecular Medicine, University of Lübeck, Lübeck, Germany; *both authors contributed equally.

Address all correspondence and requests for reprints to: Ralf Werner, PhD. Department of Pediatrics and Adolescent Medicine, Division of Paediatric Endocrinology and Diabetes, University of Lübeck, 23562 Lübeck, Germany. Email: ralf.werner@uni-luebeck.de NOTE: This preprint reports new research that has not been certified by peer review and should not be used to guide clinical practice. 
medRxiv preprint doi: https://doi.org/10.1101/2020.03.25.20041418; this version posted March 30, 2020. The copyright holder for this preprint (which was not certified by peer review) is the author/funder, who has granted medRxiv a license to display the preprint in

All rights reserved. No reuse allowed without permission.

\section{Grant Numbers}

This work was funded by financial support from Bundesministerium für Bildung und Forschung BMBF (01DQ17004), Deutsche Forschungsgemeinschaft (DFG, German Research Foundation) under Germany`s Excellence Strategy (EXC 22167-390884018), Fundação de Amparo à Pesquisa do Estado de São Paulo (\#2015/04763-4) and a scholarship from Coordenação de Aperfeiçoamento de Pessoal de Nível Superior (Programa de Doutoradosanduíche no Exterior - PDSE - 88881.135162/2016-01). 
medRxiv preprint doi: https://doi.org/10.1101/2020.03.25.20041418; this version posted March 30, 2020. The copyright holder for this preprint (which was not certified by peer review) is the author/funder, who has granted medRxiv a license to display the preprint in All rights reserved. No reuse allowed without permission.

\section{Abstract}

Duplications of dosage sensitive sex-locus Xp21.2 including NROB1 have been linked to 46,XY gonadal dysgenesis (GD) and their effects are attributed merely to increase gene dosage of NROB1 (DAX1). Here we present a general mechanism how deletions, duplications, triplications or inversions with or without $N R O B 1$ at Xp21.2 can lead to partial or complete GD by disrupting the cognate topological associated domain (TAD) in the vincinity of NROB1. Our model is supported by three unrelated patients: two showing a $287 \mathrm{~kb}$ overlapping duplication at the Xp21.2 locus upstream of NROB1 containing CXorf21 and GK and one patient having a large new triplication of Xp21.2 as the most likely cause of GD. Whole Genome sequencing uncovered the exact structural rearrangements of the duplications and the triplication. Comparison with a previously published deletion upstream of NROB1 revealed a common $35 \mathrm{~kb}$ overlap between the deletion, our newly reported NROB1 upstream duplications and the triplication as well as all other copy number variations (CNVs) at Xp21.2 reported so far. This overlap contains a strong CCCTC-binding factor (CTCF) binding site representing one boundary of the NROB1 TAD. All three CNVs at Xp21.2 most likely disrupt this TAD boundary, which isolates NROB1 from CXorf21 and GK and putatively results in GK and CXorf21 enhancer adoption and ensuing ectopic NROB1 expression. As a result, the patients' transcriptomes developed an intermediate expression pattern with both ovarian and testicular features and greatly reduced expression of spermatogenesis-related genes. This model not only allows better diagnosis of GD displaying CNVs at Xp21.2, but also gives deeper insight how spatiotemporal activation of developmental genes can be disrupted by reorganized TADs also in other rare diseases.

Keywords: 46,XY gonadal dysgenesis, Xp21.2 duplications, Xp21.2 triplication, NROB1, enhancer adoption, topologically associating domains, transcriptome analysis 
medRxiv preprint doi: https://doi.org/10.1101/2020.03.25.20041418; this version posted March 30, 2020. The copyright holder for this preprint (which was not certified by peer review) is the author/funder, who has granted medRxiv a license to display the preprint in All rights reserved. No reuse allowed without permission.

\section{Introduction:}

$46, \mathrm{XY}$ differences/disorders of sex development (DSD) with gonadal dysgenesis (GD) are characterized by a range of phenotypes from genital ambiguity to female genitalia caused by variable degrees of testicular failure. Genetic variants in more than 20 genes have been described as monogenic causes, several of these in a dose-dependent manner (Audi et al., 2018). Among such genes is NROB1 (Nuclear Receptor Subfamily 0, Group B, Member 1; also known as $D A X 1$ ), located within a dosage-sensitive $160 \mathrm{~kb}$ spanning sex reversal (DSS) region at Xp21.2 (Bardoni et al., 1994). Since its first description several 46,XY GD patients with duplications including the entire NROB1 have been reported (Figure S1, Supporting Information) (Barbaro et al., 2008; Barbaro, Cook, Lagerstedt-Robinson, \& Wedell, 2012; Barbaro et al., 2007; Dong et al., 2016; Garcia-Acero et al., 2019; Ledig et al., 2010; White et al., 2011). In mice, NrOb1 expression starts in the genital ridge of both sexes at the same time point as the expression of Sry (sex determining region $Y$ ), but is downregulated in the developing testis and persists in the ovary (Swain, Zanaria, Hacker, Lovell-Badge, \& Camerino, 1996). It has been shown that high exogenous NrOb1 expression in transgenic mice retards testis formation. Coexpression with a weak Sry allele even resulted in complete sex reversal (Swain, Narvaez, Burgoyne, Camerino, \& Lovell-Badge, 1998) resembling the NROB1 duplications in humans that cause $46, \mathrm{XY}$ GD (OMIM \#300018). Thus, NROB1 is the most plausible candidate gene for $46, \mathrm{XY}$ GD in the DSS region. In humans, NROB1 inactivating mutations cause X-linked congenital adrenal hypoplasia $(\mathrm{AHC})$ with hypogonadotropic hypogonadism (OMIM \#300200), but boys have intact testicular development at birth.

NrOb1 is known to directly repress Sox9 (Sry - box 9) expression rather than expression of upstream targets, such as Sf1 (steroidogenic factor 1; also known as NR5A1) or Sry, whose 
medRxiv preprint doi: https://doi.org/10.1101/2020.03.25.20041418; this version posted March 30, 2020. The copyright holder for this preprint (which was not certified by peer review) is the author/funder, who has granted medRxiv a license to display the preprint in All rights reserved. No reuse allowed without permission.

expression remains unchanged under NROB1 overexpression (Ludbrook et al., 2012). Sox9 is important for Sertoli cell differentiation and its activation is Sf1 dependent (Figure S2, Supporting Information) (Ludbrook et al., 2012). NROB1 exerts its anti-testis effect through disruption of both, SF1 DNA-binding and Sox9 enhancer activation in a dose-dependent manner (Ludbrook et al., 2012). However, while high NrOB1 expression is incompatible with testicular development (Swain et al., 1998) it is later required for preserving spermatogenesis (Yu, Ito, Saunders, Camper, \& Jameson, 1998) implying it itself must be precicely regulated in the testis.

Despite considerable advances in the understanding of sex development, the genetic etiology of many 46,XY GD patients still remain unclear (Audi et al., 2018; Bashamboo, Eozenou, Rojo, \& McElreavey, 2017). Besides unidentified genes in the gonadal developmental pathway, this may be due to a neglect of non-coding and regulatory elements in the molecular analysis of these patients so far. Whole genome sequencing (WGS) transcends this paradigm by providing detailed data on the complete patient genome. Here we describe three $46, \mathrm{XY}$ patients with GD have been raised as females and for whom we did not find any protein-coding variants in the genome considered as pathogenic for the phenotype. Still, a transcriptome analysis of gonadal tissue revealed expression of both testis and ovary related genes, such as SOX9 and FOXL2, respectively, and showed a greatly reduced expression of spermatogenesis pathways (Figure S3, Supporting Information). Remarkably, all three patients carry Xp21.2 copy number variations (CNVs) with a $287 \mathrm{~kb}$ overlapping region upstream of NROB1. Comparison with a published deletion at Xp21.2 (Smyk et al., 2007) narrowed this region to $35 \mathrm{~kb}$. Based on publicly available chromatin immunoprecipitation (ChIP) and chromatin conformation capture (3C, Hi-C) data (Y. Wang et 
medRxiv preprint doi: https://doi.org/10.1101/2020.03.25.20041418; this version posted March 30, 2020. The copyright holder for this preprint (which was not certified by peer review) is the author/funder, who has granted medRxiv a license to display the preprint in All rights reserved. No reuse allowed without permission.

al., 2018) we propose that this common region includes a boundary element of a topologically associating domain (TAD). The genomic duplications or the triplication and the deletion upstream of NROB1 disrupts this TAD and the association of the genes and their specific regulatory elements therein. This would result in upregulation of NROB1 expression which causes suppression of SOX9, disrupting Sertoli cell differentiation and successful testis-development (Chaboissier et al., 2004).

\section{Patients and Methods}

\section{Editorial Policies and Ethical Considerations}

This study was approved by local Ethics Committees of the Universities of Campinas (CAAE 24972513.5.0000.5404) and Lübeck (AZ 17-219). Written informed consent was obtained from the patients and/or their parents/legal guardians.

\section{Patients}

Three unrelated patients from Brazil and Germany were investigated in the study.

Patient 1 (P1): The patient was referred to the DSD clinic, State University of Campinas at age of 5 days, due to genital ambiguity. She was born at term after an uneventful pregnancy with birth weight of $3,410 \mathrm{~g}$ and a length of $49 \mathrm{~cm}$. She had a $0.5-\mathrm{cm}$ phallus, a single perineal opening, partially fused labioscrotal folds and non-palpable gonads (External Masculinization Score - EMS = 4) (Ahmed, Khwaja, \& Hughes, 2000). Abdominal ultrasound revealed no abnormalities and genitography showed a urogenital sinus. The karyotype was 46, XY and fluorescence in situ hybridization (FISH) displayed no 45, X cell line. Laparoscopy showed absence of uterus, likewise the left gonadal tissue was absent and there was a right 
medRxiv preprint doi: https://doi.org/10.1101/2020.03.25.20041418; this version posted March 30, 2020. The copyright holder for this preprint (which was not certified by peer review) is the author/funder, who has granted medRxiv a license to display the preprint in

All rights reserved. No reuse allowed without permission.

dysgenetic testis with some areas of fibrous tissue surrounding immature seminiferous tubules without spermatogonia. When she was 1 month old, hormonal evaluation revealed high FSH (24 IU/I; normal range: 1.5 to $12.4 \mathrm{IU} / \mathrm{I})$ and LH (10 IU/I; NR: 1.7 to $8.6 \mathrm{IU} / \mathrm{I})$ levels and low testosterone $(0.2 \mathrm{ng} / \mathrm{ml}$; NR: 2.86 to $8.10 \mathrm{ng} / \mathrm{ml})$, suggestive of testicular failure due to partial GD.

Patient 2 (P2): First presentation in the University DSD center in Kiel and Lübeck occurred at the age of 17 years and 2 months due to primary amenorrhea and pubertal delay. The girl previously had a dysgerminoma which was removed 3 months earlier. Tanner stages were B4, P4-5. However, breast development started only at the age of 16 years, a few months before clinical diagnosis of the dysgerminoma. External genitalia were completely female without clitoromegaly and a uterus with tubular configuration was present. The karyotype was 46,XY. Hormonal evaluation revealed basal LH $53 \mathrm{IU} / \mathrm{I}$ and FSH $94.3 \mathrm{IU} / \mathrm{I}$ increasing to $200 \mathrm{IU} / \mathrm{I}$ and $128 \mathrm{IU} / \mathrm{I}$, respectively, $30 \mathrm{~min}$ following $60 \mu \mathrm{g} / \mathrm{m}^{2} \mathrm{GnRH}$ i.v.. Plasma estradiol was $9 \mathrm{pg} / \mathrm{ml}$ (prepubertal for girls) and testosterone $123 \mathrm{ng} / \mathrm{dl}$ (mid-pubertal for males) (both determined by LC-MS/MS) (Kulle, Riepe, Melchior, Hiort, \& Holterhus, 2010). Plasma $\mathrm{AMH}$ was $0.71 \mu \mathrm{g} / \mathrm{l}$ and therefore extremely low. Therefore, the clinical diagnosis of GD was established.

Patient 3 (P3):

This patient was born at term after an uneventful pregnancy and genital status was described as unequivocal female. The family history is unremarkable, with three healthy siblings. Because of muscular hypotonia, a chromosomal analysis was initiated and revealed a 46,XY karyotype. On ultrasound, a small prepubertal uterus was seen, but the gonads were 
medRxiv preprint doi: https://doi.org/10.1101/2020.03.25.20041418; this version posted March 30, 2020. The copyright holder for this preprint (which was not certified by peer review) is the author/funder, who has granted medRxiv a license to display the preprint in All rights reserved. No reuse allowed without permission.

not visualized. Hormone analysis showed a prepubertal status with inhibin B below the threshold and anti-Mullerian hormone at $0.42 \mu \mathrm{g} / \mathrm{l}$, which was considered low for age, compatible with a clinical diagnosis of gonadal dysgenesis. A laparoscopy was performed and the gonadal tissue removed. The histology revealed a gonadoblastoma of the right gonad, while the left side was purely stromal tissue.

\section{Multiplex ligation dependent probe amplification (MLPA)}

To identify DNA gains and losses, multiplex-ligation dependent probe amplification (MLPA) assays were performed for P1 using two different kits: SALSA MLPA kit P185-C1 Intersex probemix and SALSA MLPA P334-A2 Gonadal Development Disorder probemix (MRCHolland, Amsterdam, The Netherlands). The MLPA assay was carried out according to the standard protocol supplied by MRC-Holland. Data were analysed by comparison of the peaks obtained from the tested samples and those from controls using the software Coffalyser.NET (MRC-Holland, Amsterdam, The Netherlands).

\section{Chromosomal microarray analysis (CMA)}

Chromosomal microarray analyses were performed using two different platforms. DNA samples from P1 and her mother were hybridised onto the GeneChip CytoScan ${ }^{\circledR} 750 \mathrm{~K}$ Array Kit (Affymetrix Inc., Santa Clara, California, USA) and processed as recommended by the manufacturer. Array data were analysed using Chromosome Analysis Suite (ChAS) (Affymetrix ${ }^{\circledR}$ ). Standard analysis adopted the following parameters: markers $>25$ for deletion; >50 for duplication, without filter size for copy number variations (CNVs). DNA of P2 and P3 was hybridized to an Agilent 180K comparative genomic hybridization array (aCGH) (Agilent Technologies, Inc) and compared to a pooled sample of 10 normal males. 
medRxiv preprint doi: https://doi.org/10.1101/2020.03.25.20041418; this version posted March 30, 2020. The copyright holder for this preprint (which was not certified by peer review) is the author/funder, who has granted medRxiv a license to display the preprint in All rights reserved. No reuse allowed without permission.

Data were analysed using CytoGenomics Software version 4.0.2.21 (Agilent). CNVs of both patients were analysed using the Database of Genomic Variants (DGV, Version CNV_DGV_hg19_v4, Toronto, Canada).

\section{Whole Genome sequencing (WGS)}

WGS was performed to identify deleterious point mutations and indels as well as structural variations and to fine map the breakpoints of the duplications and triplication at Xp21.2 observed in the three patients. Sequencing libraries were constructed from 1.0 $\mu$ g DNA per sample using the Truseq Nano DNA HT Sample preparation Kit (Illumina, USA) following the recommendations of the manufacturer. Genomic DNA was randomly fragmented to a size of approximately 350 bp by Covaris cracker (Covaris, USA). DNA fragments were blunted, Atailed and ligated with the full-length adapter for Illumina sequencing with further PCR amplification. Libraries were purified using AMPure XP (Beckman Coulter, USA), analysed for size distribution on an Agilent 2100 Bioanalyser (Agilent Technologies) and quantified by qPCR. Paired end sequencing of libraries was performed on Illumina HiSeq platforms (Illumina). Per sample more than $90 \mathrm{~GB}$ of raw data were obtained, resulting in an average genomic read depth of 30x.

\section{$\underline{\text { Bioinformatics }}$}

Sequencing reads were mapped to human reference genome version GRCh37/hg19 using Burrows-Wheeler Aligner (BWA)(Li \& Durbin, 2009). Resulting mapping files were screened for duplicated reads applying Picard tools MarkDuplicates version 1.111 (Picard:

http://sourceforge.net/projects/picard/). Split-reads and discordant paired-end alignments were extracted using SAMtools version 0.1.18 (Li \& Durbin, 2009). SNPs and InDels were 
medRxiv preprint doi: https://doi.org/10.1101/2020.03.25.20041418; this version posted March 30, 2020. The copyright holder for this preprint (which was not certified by peer review) is the author/funder, who has granted medRxiv a license to display the preprint in All rights reserved. No reuse allowed without permission.

called using HaplotypeCaller as implemented in Genome Analysis Toolkit (GATK) version 3.8.0 (DePristo et al., 2011) with standard parameters. Detection of structural variations (SV) was performed using DELLY (Rausch et al., 2012). Variations were annotated using ANNOVAR (K. Wang, Li, \& Hakonarson, 2010). All chromosomal positions in the paper are according to GRCh37/hg19.

\section{Breakpoint Sequencing}

Primers at either end of the constructed breakpoint sequences were designed using Lasergene PrimerSelect (DNASTAR, Wisconsin, USA). Optimal annealing temperature was determined through gradient PCR and electrophoresis. Consequently, PCR setup was 35 cycles with $30 \mathrm{sec}$. at $95^{\circ} \mathrm{C}$ for denaturation, $30 \mathrm{sec}$. at primer specific temperature (Table S2, Supporting Information) for annealing and $1 \mathrm{~min}$. extension at $72^{\circ} \mathrm{C}$. Sanger Sequencing of amplicons was performed on a 3130 Genetic Analyzer (Applied Biosystems, Foster City, USA).

\section{$\underline{\text { Transcriptome Analysis }}$}

Transcriptome analysis was performed from 10 slices $(10 \mu \mathrm{m})$ of formalin fixed paraffin embedded (FFPE) samples of the gonads of patients 1 and 2. Library preparation was performed employing the TruSeq stranded Total RNA kit (Illumina Inc.), and sequenced on an Illumina NovaSeq platform (150-nucleotide paired-end reads), obtaining 98 and 63 million reads for patient 1 and 2, respectively. Fastq reads were pseudo-aligned to the Ensembl cDNA sequence Grch38 transcriptome assembly in version 96 using kallisto (Bray, Pimentel, Melsted, \& Pachter, 2016). Gene transcript read counts were aggregated to Ensembl Gene IDs for further analysis (Soneson, Love, \& Robinson, 2015) and genes with an expression less 
medRxiv preprint doi: https://doi.org/10.1101/2020.03.25.20041418; this version posted March 30, 2020. The copyright holder for this preprint (which was not certified by peer review) is the author/funder, who has granted medRxiv a license to display the preprint in All rights reserved. No reuse allowed without permission.

than one transcript per million (TPM) in either sample discarded, resulting in 13005 expressed genes.

Patient transcriptomes from expressed genes were compared to testis and ovary tissue samples from the GTEx Database (Carithers et al., 2015) and the data set E-MTAB-6814 from ArrayExpress (Athar et al., 2019), a human RNAseq time-series of the development of seven major organs.

To compare transcriptome similarity, we performed a dimensionality reduction using tdistributed stochastic neighbor embedding (t-SNE) (van der Maaten, 2014) as implemented in the R library Rtsne (version 0.15) (Krijthe, 2015). The analysis is based on 641 samples and 5000 randomly selected genes, expressed in both patient tissues.

Differential pathway activity between samples was determined by a Gene Set Variation Analysis (GSVA) (Hanzelmann, Castelo, \& Guinney, 2013), which calculates the relative enrichment of gene sets across individual samples using a non-parametric approach. For pathway and upstream transcription factor activity we used the hallmark gene set collection (Liberzon et al., 2015) and the TF-target relationship from Schacht et al (2014) (Schacht, Oswald, Eils, Eichmuller, \& Konig, 2014). The enrichment scores were tested for significant differences using a moderated t-test per time point (Ritchie et al., 2015).

\section{Results}

Patient 1

CMA revealed $\mathrm{a} \approx 277 \mathrm{~kb}$ duplication at $\mathrm{Xp} 21.2[30,580,693-30,857,187]$ that was supported by MLPA (Figure S4, Supporting Information). Analysis of the mother showed the same duplication. WGS confirmed this structural variation (SV) in the patient showing a $297 \mathrm{~kb}$ duplication of GK (glycerol kinase), CXorf21 (chromosome X open reading frame 21) and part 
medRxiv preprint doi: https://doi.org/10.1101/2020.03.25.20041418; this version posted March 30, 2020. The copyright holder for this preprint (which was not certified by peer review) is the author/funder, who has granted medRxiv a license to display the preprint in All rights reserved. No reuse allowed without permission.

of TAB3 (TGF beta activated kinase 1 binding protein 7, MAP3K7). Duplication borders were apparent through increased read-depth and split reads mapping $297 \mathrm{~kb}$ apart. Paired split reads were extracted and aligned to generate a continuous sequence of the breakpoints showing a tandem duplication, where intron 9 of $T A B 3$ is merged to the downstream region of $C X o r f 21$ by a $27 \mathrm{bp}$ insert (Figure 1). The sequences at the breakpoint were confirmed by PCR and Sanger sequencing. Only two heterozygous missense SNVs were found in protein coding regions of genes related to 46,XY DSD (Table S1, Supporting Information). However, heterozygous pathogenic variants in both genes (STAR/POR) were excluded as putative cause of sex steroid biosynthesis deficiency.

\section{Patient 2}

WGS revealed two major duplications and two small deletions at Xp21.2; one duplication of $389 \mathrm{~kb}$ maps to a region downstream of NROB1 containing the MAGEB (MAGE family member B) genes 1-4 and a part of ILIRAPL1 (interleukin 1 receptor accessory protein like 1). The second duplication $(447 \mathrm{~kb})$, containing CXorf21 and GK as well as the $3^{\prime}$-part of TAB3, maps upstream of NROB1. Between the two duplications two small deletions of $2.7 \mathrm{~kb}$ (Deletion I) and $2.2 \mathrm{~kb}$ (Deletion II) flank an inverted region of 1.2kb (Figure 2; Figure S5, Supporting Information). As in P1, split read pairs at the borders of the four copy number variations (CNVs) were utilized to construct continuous breakpoint sequences and thus determine orientation and location of the inserted duplications. Both duplications are inserted upstream of $N R O B 1$ as described in Figure 2. Notably, the $447 \mathrm{~kb}$ duplication encompassing CXorf21, GK and the TAB3 fragment is inserted proximal to NROB1 in an inverted position. The $389 \mathrm{~kb}$ duplication of MAGEB1-4 and the IL1RAPL1 fragment was inserted further upstream in the same orientation as the reference sequence. Breakpoint sequences were 
medRxiv preprint doi: https://doi.org/10.1101/2020.03.25.20041418; this version posted March 30, 2020. The copyright holder for this preprint (which was not certified by peer review) is the author/funder, who has granted medRxiv a license to display the preprint in All rights reserved. No reuse allowed without permission.

confirmed by Sanger sequencing (Figure 2) and copy number gains and losses predicted from WGS, were confirmed by aCGH (Figure S5, Supporting Information). WGS of the parents established that the SV was inherited maternally. Furthermore, only one rare variant $(\mathrm{MAF}<0.01)$ of unknown significance was found in the known DSD candidate gene ZFPM2 (zinc finger protein, FOG family member 2). Although ZFPM2 variants are associated with abnormalities in testis determination, the average population frequency of this SNV (dbSNP:rs202217256) is 0.004 across all populations and 0.006 in the Non-Finish European population according to the ExAc Browser (Lek et al., 2016), which indicates a rare polymorphism (Table S1, Supporting Information), rather than a relevant pathogenic variant leading to GD.

\section{Patient 3}

P3 harbors a Xp21.2 triplication initially identified through qPCR copy number detection (Meinel, Dwivedi, Holterhus, Hiort, \& Werner, 2019). In contrast to P1 and P2 this patients CNV also includes the NROB1 gene. An aCGH (Figure S6, Supporting Information) characterized the size of the triplication to be $\approx 1,22 \mathrm{Mb}$, which was later rendered more precisely by WGS to be 1,24 Mb. The triplication includes the genes MAGEB1-4, NROB1, CXorf21, GK, TAB3 and part of IL1RAPL1. The triplicated segments are arranged in tandem to their template and are separated by a 49bp insert (ChrX:31,258,118-31,258,166) (Figure S7, Supporting Information). The insert originates form the $D M D$ gene, which is located to the centromeric side of the CNV. Analysis of exome data of known DSD candidate genes revealed heterozygous missense SNVs, which all showed interpretations as benign or likely benign in ClinVar, except for one in Estrogen Receptor 2 (ESR2) (Tabele S1, Supporting Information). The clinical significance of this SNV (dbSNP: rs367855747) has not been 
medRxiv preprint doi: https://doi.org/10.1101/2020.03.25.20041418; this version posted March 30, 2020. The copyright holder for this preprint (which was not certified by peer review) is the author/funder, who has granted medRxiv a license to display the preprint in All rights reserved. No reuse allowed without permission.

reported so far, however recently homo- and heterozygous ESR2 mutations have been described in the context of 46,XY partial and complete GD (Baetens et al., 2018). The effect of this particular heterozygous SNV remains unclear, but in the context of widely agreed association of $N R O B 1$ copy number gains and $46, X Y$ DSD this remains a subordinate factor in the etiology, if at all.

\section{Analysis of Topologically Associating Domains}

SVs affecting boundaries of topologically associating domains (TADs) have been shown to alter the architecture and enhancer-promoter interactions within TADs with effects on development (Ibn-Salem et al., 2014; Lettice et al., 2011; Lupianez et al., 2015) and oncogenesis (Hnisz et al., 2016; Weischenfeldt et al., 2017). We analyzed the TADs in the NROB1 region identified by capture $\mathrm{Hi}-\mathrm{C}$ from various human cell lines provided by the Penn State 3D genome browser (Y. Wang et al., 2018). Most cell lines show a clear compartmentalization of NROB1 into a TAD (referred to hereafter as NROB1 TAD) that is separated from the enhancer elements of the CXorf21 and GK genes (Figure S8, Supporting Information).

When comparing the two duplications and the triplication observed in our patients with a previously published $257 \mathrm{~kb}$ deletion in the NROB1 upstream region (Smyk et al., 2007), also associated with $46, \mathrm{XY}$ GD, there is a $35 \mathrm{~kb}$ overlap region among all four (Figure S1, Supporting Information). This region contains a strong binding site for CTCF (CCCTC binding factor), RAD21 and SMC3 (structural maintenance of chromosomes 3) (Figure S9, Supporting Information), which are involved in chromatin extrusion complexes and contact domain formation and are characteristic of TAD boundaries (de Wit et al., 2015; Sanborn et al., 
medRxiv preprint doi: https://doi.org/10.1101/2020.03.25.20041418; this version posted March 30, 2020. The copyright holder for this preprint (which was not certified by peer review) is the author/funder, who has granted medRxiv a license to display the preprint in All rights reserved. No reuse allowed without permission.

2015). Thus, the binding sites in intron 2 of CXorf 21 most probably correspond to the NROB1 TAD boundary site that is observed in most cell types.

\section{Transcriptome Analysis of FFPE Gonadal Tissue}

We compared the gonad transcriptomes from patient 1 and 2 to testis $(n=156)$ and ovary tissue ( $n=133$ ) transcriptomes that were obtained from the GTEx project and a human RNAseq time-series from ArrayExresss containing tissue transcriptomes from seven major organs (brain $(n=66)$, cerebellum $(n=59)$, heart $(n=46)$, kidney $(n=37)$, liver $(n=50)$, fetal ovary $(n=18)$, fetal to infant testis $(n=29)$ and teenager to old testis $(n=10))$ across different ages from fetal, infant, and teenager to adult and senior age. Lowly-expressed genes $($ TPM $<1)$ in the patients' samples were discarded, leaving 13005 common genes. A t-SNE analysis reveals a strong tissue-specific clustering of all transcriptomes, independent of their experimental origin (Figure 3). Interestingly, fetal and young ovary and testis samples (pink and purple dots) cluster together, while adult ovary and testis samples (red and yellow/orange) significantly differ in their gene expression and cluster distinctly from any other organ. The samples of patient 1 and 2 are situated between the adult ovary and testis samples, yet close to patient samples that were reported by the GTEx project as having low spermatogenesis.

Figure S3 (Supporting Information) depicts boxplots of several sex determination genes from the GTEx ovary and testis samples used in Figure 3 and the two patients. Obviously, all genes are differentially expressed in the two tissues, but also between the patients and the ovary as well as the testis samples. For example, the forkhead transcription factor FOXL2, which is essential for ovary differentiation and maintenance, repressing the genetic program for somatic testis determination (Boulanger et al., 2014; Uhlenhaut et al., 2009), is highly specific to ovarian tissue, yet it is expressed at intermediate strength in the two patient samples with 
medRxiv preprint doi: https://doi.org/10.1101/2020.03.25.20041418; this version posted March 30, 2020. The copyright holder for this preprint (which was not certified by peer review) is the author/funder, who has granted medRxiv a license to display the preprint in All rights reserved. No reuse allowed without permission.

the expression in P2 exceeding that of P1. In contrast, the Doublesex and Mab-3 Related Transcription Factor 1 DMRT1 is a transcription factor playing a key role in male sex determination and differentiation by controlling testis development and Sertoli cell maintenance (Ledig, Hiort, Wunsch, \& Wieacker, 2012; Matson et al., 2011) is expressed in testis, but not in ovarian tissue. Yet, the patients' gonads express this gene at an intermediate level.

This intermediate gene expression state is reflected by Gene Set Variation Analysis using the hallmark gene sets from the MSigDB (Liberzon et al., 2015) on 6 randomly selected testis and ovary tissues as well as the median tissue expression values from GTEx and the patient samples. The analysis shows how the latter have acquired expression programs from both tissues and cluster in between the ovary and testis samples. The most active pathway in testis is spermatogenesis. This pathway is not expressed in the ovary samples, yet low, but significantly higher in the patients. Interestingly, MYC signaling is present is both sample groups, but completely absent in the two patient samples (Figure S10A, Supporting Information). The latter finding is supported by comparing the putative activity of upstream transcription factors. While the patient samples share activity from both ovary and testis specific TFs, there is a low activity of RFX2 and E2F6 (Figure S10B, Supporting Information). $\mathrm{RFX} 2$ is a as a key regulator of spermatogenesis through regulation of genes required for the haploid phase during spermiogenesis (Kistler et al., 2015), while E2F6 is critically involved in cell cycle progression (Giangrande et al., 2004). In combination with reduced MYC pathway activity, this might hint at reduced cell proliferation, which is indeed the case based on Reactome cell cycle pathways (Figure S10C, Supporting Information).

\section{Discussion}


medRxiv preprint doi: https://doi.org/10.1101/2020.03.25.20041418; this version posted March 30, 2020. The copyright holder for this preprint (which was not certified by peer review) is the author/funder, who has granted medRxiv a license to display the preprint in All rights reserved. No reuse allowed without permission.

Because all known genetic causes of 46,XY GD were excluded by WGS, the Xp21.2 CNVs remain as the only likely cause identified in our three patients. The overlap of the NROB1 upstream duplicated region in P1 \& P2 spans 287kb (Figure S11, Supporting Informaton) and is also contained in the triplication of P3. The $287 \mathrm{~kb}$ region includes the genes GK and CXorf21 together with their respective promoter and predicted enhancer regions as well as the 3'-end of TAB3 (Figure S12, Supporting Information). To our knowledge, no similar case with a Xp21.2 duplication excluding NROB1 or Xp21.2 triplication including NROB1 has been described in patients with 46,XY GD so far.

In recent years the role of three-dimensional chromosome structures and their organization in TADs have moved into the focus of genome research (Dixon et al., 2012). TADs are nonrandomly organized up to megabase-sized local chromatin interaction domains that are thought to guide regulatory elements to their cognate promoters and provide insulation for non-cognate genes. These domains can be stable across different cell lines and conserved across species (Dixon et al., 2012).

TAD formation generally requires two corresponding CTCF motifs - one at either end of the loop forming domain. It has been shown that these motifs are predominantly oriented in a convergent manner (de Wit et al., 2015; Guo et al., 2015; Vietri Rudan et al., 2015) and that elimination or change of CTCF orientation can lead to removal or shift of TAD boundaries (Lupianez, Spielmann, \& Mundlos, 2016; Sanborn et al., 2015). The two duplications reported in this study and the deletion reported by Smyk et al. (2007) have a 35kb overlapping region harboring a CTCF motif in proximity to the identified NROB1 TAD border (Figure S8 and Figure S9, Supporting Information). This CTCF is orientated towards NROB1, which fits well into a concept of it being the centromeric end point of the NROB1 TAD (Figure S13, Supporting Information). 
medRxiv preprint doi: https://doi.org/10.1101/2020.03.25.20041418; this version posted March 30, 2020. The copyright holder for this preprint (which was not certified by peer review) is the author/funder, who has granted medRxiv a license to display the preprint in All rights reserved. No reuse allowed without permission.

$\mathrm{Hi}-\mathrm{C}$ data suggest a boundary region between the NROB1 TAD and the adjacent centromeric TAD (Figure S8, Supporting Information) (Y. Wang et al., 2018). In most cell lines this boundary region includes Exon 1 and 2 of CXorf 21 and GK together with their respective promoters and predicted enhancers (Figure S10, Supporting Information). Thus, NROB1 is shielded from these non-cognate enhancers by just a single CTCF. The discussed SVs might enable enhancers to bypass the insulating effect of this CTCF binding motif (Figure S13, Supporting Information) and allow ectopic interactions with NROB1, a process known as enhancer adoption (Lettice et al., 2011) through positioning in a common loop forming domain (Figure 4). This could lead to up regulation or aberrant expression of NROB1, which in consequence results in decreased SF1-mediated SOX9 expression and impaired testicular development (Figure S2, Supporting Information). This is in accordance with the fact that all three patient's SVs described, the deletion reported by Smyk et al. (2007), as well as previously published duplications containing NROB1 and CXorf21 had maternal origin (Barbaro et al., 2012; Barbaro et al., 2007; Smyk et al., 2007).

The tandem duplication in P1 inserts an additional left oriented CTCF motif (Figure S13, Supporting Information). However, according to the cohesin-dependent loop extrusion model for the formation of TADs, only one of these two CTCF motifs can interact with the oppositely oriented CTCF that defines the telomeric NROB1 TAD boundary (Fudenberg et al., 2016; Sanborn et al., 2015). Loop extrusion is believed to be a dynamic process (Rao et al., 2017), whereby structural maintenance of chromosomes (SMC) complex's (cohesin) translocate along the chromosomes in an ATP dependent process producing expanding loops of chromatin. This process brings together increasingly distant genomic loci and continues until the cohesin complex either dissociates or meets a barrier in the form of a convergent CTCF. If one side of the complex encounters a barrier it is assumed that 
medRxiv preprint doi: https://doi.org/10.1101/2020.03.25.20041418; this version posted March 30, 2020. The copyright holder for this preprint (which was not certified by peer review) is the author/funder, who has granted medRxiv a license to display the preprint in All rights reserved. No reuse allowed without permission.

chromatin extrusion continues on the other end until equally a convergent CTCF is met (Fudenberg et al., 2016; Goloborodko, Marko, \& Mirny, 2016). Though this is a dynamic process of cohesin loading and dissociation there is an increased time of residence at TADboundaries (Szabo, Bantignies, \& Cavalli, 2019).

The arrangement in P1 gives rise to two putative TAD conformations with either the proximal or distal NROB1 oriented CTCF constituting the centromeric NROB1 TAD boundary (Figure 4 and Figure S13, Supporting Information) with increased time of cohesin residence at both.

In situations where the NROB1 TAD is formed with the distal left oriented CTCF, it encompasses the whole duplicated segment which could allow the non-cognate enhancers to interact with NROB1 and may result in enhancer adoption (Figure 4, P1a).

The identified inversion in P2 brings GK and CXorf21, along with their corresponding putative enhancers, into the NROB1 TAD without its inverted CTCF interfering with the existing borders (Figure 4 and Figure S13, Supporting Information). The previously outlying non-cognate enhancers are putatively inside the NROB1 TAD and may interact with the NROB1 promoter (Figure 4).

De Wit et al. (2015) also studied the deletion of individual CTCF motifs, leaving the partnering CTCF motif abandoned. Though bound by CTCF and cohesin, these formerly partnering CTCF motifs did not engage in new loops with other CTCFs. Following from this, the deletion reported by Smyk et al. (2007) most likely leads to a disruption of the TAD between the convergent sites rather than the formation of a new TAD towards a different CTCF. Several groups have studied the deletion of TAD boundaries and individual CTCF sites in different cells and organisms in recent years (Gomez-Marin et al., 2015; Narendra et al., 
medRxiv preprint doi: https://doi.org/10.1101/2020.03.25.20041418; this version posted March 30, 2020. The copyright holder for this preprint (which was not certified by peer review) is the author/funder, who has granted medRxiv a license to display the preprint in All rights reserved. No reuse allowed without permission.

2015; Nora et al., 2012; Sanborn et al., 2015) showing that these result in ectopic interaction outside the previous TAD conformation. According to our model, TAD-conformation is confined to one arrangement with increased time of residence in P2 and in the patient reported by Smyk et al. (2007). The difference in the putative DNA target structures and that probability of produceing a TAD including both, NROB1 and the ectopic enhancers (Figure 4) could help explain the differences in phenotype of the patients. In contrast to P2, P3 and the patient reported by Smyk et al. (2007), the phenotype of P1 is less severe. The absence of a uterus in P1 implies the presence of Sertoli cells with intact production of anti-Müllerian hormone, while the other two patients (P2 and the one reported by Smyk et al, 2007) resemble a higher degree of accordance in phenotype, as both presented a small uterus and low estrogens with late onset of breast development.

In all three patients with complete gonadal dysgenesis presumed TAD-conformations bringing $N R O B 1$ and the non-cognate enhancers into a common domain. This is in contrast to P1, displaying partial gonadal dysgenesis, where the duplication allows a partial normal TAD conformation (Figure S7, Supporting Information). According to the loop extrusion model a multiplication of NROB1 and the insulator at CXorf21 as well as the CXorf21 and GK enhancers as present in P3, one of the duplicated CXorf21 insulators loses its function due to the lack of an opposing interaction partner, whilst NROB1 and enhancers maintain their function with respect to the phenotype. Therefore, it is possible that this model describes a general process beyond the specific genetic rearrangements of the three patients presented here and the deletion reported by Smyk et al. (2007) and would similarly apply to all previously reported Xp21.2 duplications (Barbaro et al., 2008; Barbaro et al., 2012; Barbaro et al., 2007; Dong et al., 2016; Garcia-Acero et al., 2019; Ledig et al., 2010; White et al., 
medRxiv preprint doi: https://doi.org/10.1101/2020.03.25.20041418; this version posted March 30, 2020. The copyright holder for this preprint (which was not certified by peer review) is the author/funder, who has granted medRxiv a license to display the preprint in All rights reserved. No reuse allowed without permission.

2011). It is of note, that $\mathrm{P} 3$ also shows muscular hypotonia possibly hinting at a regulatory effect of the triplication on the expression of the $D M D$ gene.

The phenotype of Xp21.2 duplications has previously been associated with dosage effects of the duplicated genes (Barbaro et al., 2007; Bardoni et al., 1994). Recent advancements in the analysis and understanding of DNA conformation highlight the importance of intact TADs for unaltered enhancer-promoter interactions (Franke et al., 2016; Lupianez et al., 2016). With our newly discovered cases, it is not NROB1 itself as the unifying cause in all Xp21.2 copy number gains associated with $46, \mathrm{XY} G D$, but instead it is the $35 \mathrm{~kb}$ upstream region, which is present in every reported case thus far (Figure 1, Supplemental Information). This underlines the necessity to reevaluate all previously reported Xp21.2 duplications, as the fundamental mechanism might be a different one then previously assumed.

Further, knowing the position and orientation of SVs alongside the new arrangement of enhancers and genes could become increasingly relevant for understanding genotypephenotype relationship. This underscores the potential diagnostic power of whole genome sequencing, which allows accurate characterization of SVs through interrogation of individual reads at breakpoints as shown in this study.

As a result of the gene duplication, the transcriptomes of the two patients obtain an intermediate gene expression state between ovary and testis samples. Gene expression analysis clearly clusters adult ovarian and testicular tissues apart and separate from other organ tissues. The two patient samples cluster in between the two tissues, yet closer to testis and particularly close to patient tissues with low spermatogenesis. This interemediate state is further corroborated by the expression of sex determination genes (Figure S3, 
medRxiv preprint doi: https://doi.org/10.1101/2020.03.25.20041418; this version posted March 30, 2020. The copyright holder for this preprint (which was not certified by peer review) is the author/funder, who has granted medRxiv a license to display the preprint in All rights reserved. No reuse allowed without permission.

Supporting Information). Particularly FOXL2 and DMRT1, which are hallmarks of ovarian and testicular tissue, are expressed at an intermediate level, which might be either a cause or the effect of deregulation of multiple sex determination regulators in a patient specific manner. This finding is confirmed by the gene set variation analysis using the hallmark gene sets. Both P1 and P2 show a greatly reduced expression of spermatogenesis-related genes. The latter might stem from the low expression of the transcription factor Regulatory Factor X2 (RFX2) (Figure S10B, Supporting Information), which is not only a major component of spermatogenetis in human and mouse, but also regulates cell cycle (Horvath, Kistler, \& Kistler, 2004; Kistler et al., 2015). In line with this we see low activity of the upstream cellcycle related E2F transcription factor $6(\mathrm{E} 2 \mathrm{~F} 6)$ and cell cycle pathways are reduced in activity relative to both healthy ovary and testis tissue (Figure S10C, Supporting Information). Interestingly, MYC pathway activity is low compared to both the ovarian and the testicular tissue. MYC controls vertebrate development and contributes to developmental disorders (Hurlin, 2013). One might speculate whether the Xp21.2 duplications cause a hold of development of all or a subset of gonadal tissue cells, which is reflected by the findings from the transcriptome analysis, but which will require further in depth investigation and in vivo/In vitro confirmation.

In summary, our results demonstrate the relevance of genetic analysis beyond primary candidate genes and emphasize the importance of including more detailed analyses of genetic alterations affecting non-coding regulatory elements to routine diagnostics. This could be an important finding for uncovering novel genetic causes and understanding pathogenesis in DSD, and for patients with other disorders of unknown etiology. The findings further illustrate limitations of current diagnostic routines that are aCGH or MLPA based, as 
medRxiv preprint doi: https://doi.org/10.1101/2020.03.25.20041418; this version posted March 30, 2020. The copyright holder for this preprint (which was not certified by peer review) is the author/funder, who has granted medRxiv a license to display the preprint in All rights reserved. No reuse allowed without permission.

the obtained data are insufficient to evaluate most of the duplications of unknown significance. Much more research will be necessary to understand mechanisms of insulation and how regulatory elements find targets within TADs in order to completely apprehend the effect of SVs and also to make full use of techniques such as WGS in the context of sex development and far beyond.

\section{Acknowledgments}

The authors are truly grateful to the patients and families of these patients who cooperated in this study. The collaboration was based on the COST Action BM1303 DSDnet. H.B. and A.K. acknowledge computational support from the Lübeck OmicsCluster. This work is part of the doctoral thesis of J.A.M and A.P.S..

\section{Figures:}

(A)

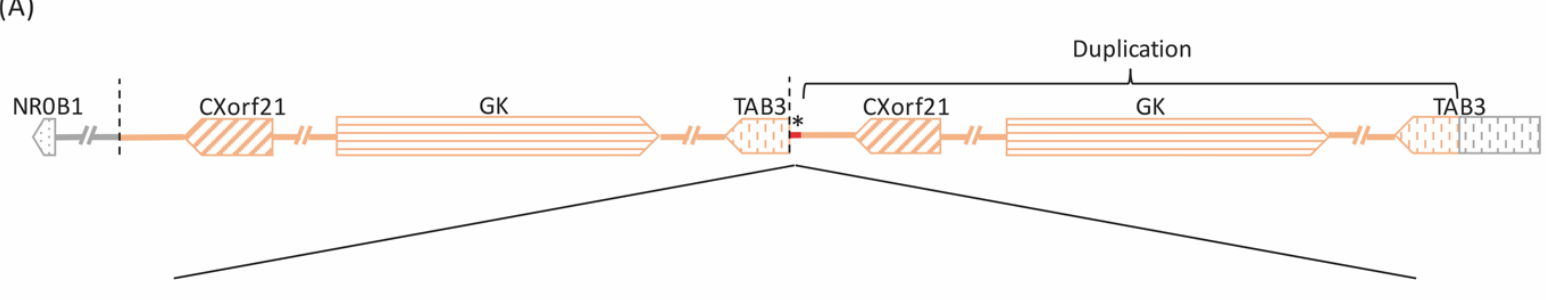

(B)

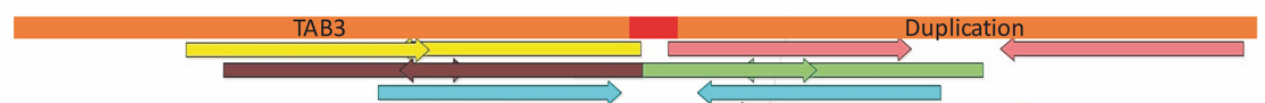

Split Reads

(C)
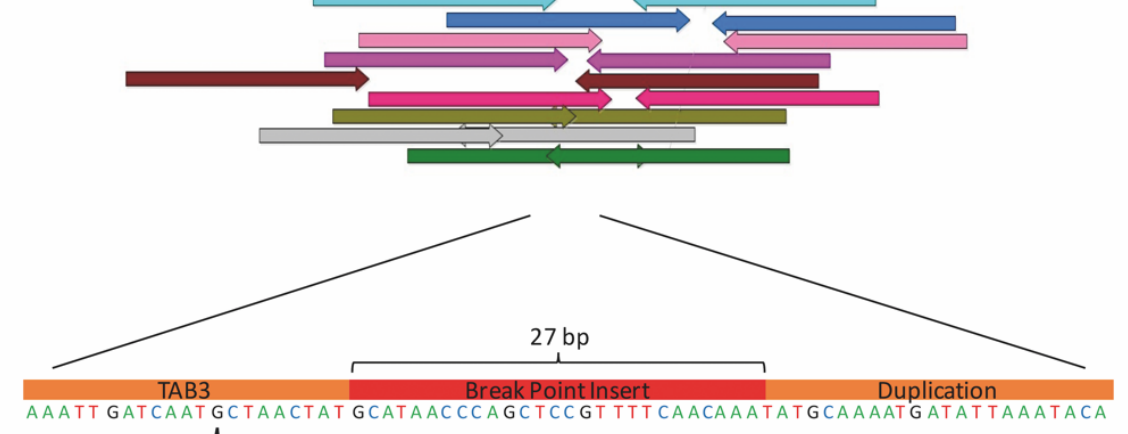

Sanger Sequence

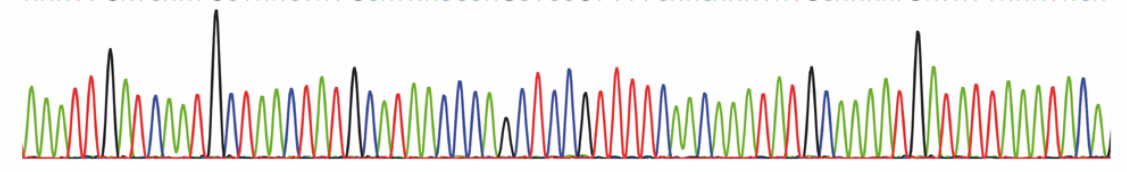


medRxiv preprint doi: https://doi.org/10.1101/2020.03.25.20041418; this version posted March 30, 2020. The copyright holder for this preprint (which was not certified by peer review) is the author/funder, who has granted medRxiv a license to display the preprint in All rights reserved. No reuse allowed without permission.

Figure 1. Structural Variation of Patient 1 (A) Overview of the copy number variation (CNV) in P1 upstream of the NROB1 gene and its orientation within the Xp21.2 region. Arrows depict genes and their respective direction of transcription. The chromosome segment is drawn with the distal chromosome arm to the left and centromere to the right. The distances between genes are not to scale. The region chrX: 30,561,644-30,859,140 has been duplicated in a tandem manner, as indicated by the segments shaded orange. * marks a 27bp insert at the breakepoint. (B) Position of extracted and aligned split reads from genome sequencing crossing the breakpoint (chrX:30,859,140). Correspondingly coloured arrows of opposite direction belong to the same read pair. Read pairs have been mapped 297.5kb away from each other. (C) Verification of the breakpoint sequence by PCR and Sanger sequencing. Electropherogram shows a contiguous sequence from the TAB3 gene to the breakpoint, an inserted sequence of $27 \mathrm{bp}$ (red) and the downstream sequence of the CXorf21 gene at the beginning of the duplication. 
medRxiv preprint doi: https://doi.org/10.1101/2020.03.25.20041418; this version posted March 30, 2020. The copyright holder for this preprint (which was not certified by peer review) is the author/funder, who has granted medRxiv a license to display the preprint in All rights reserved. No reuse allowed without permission.

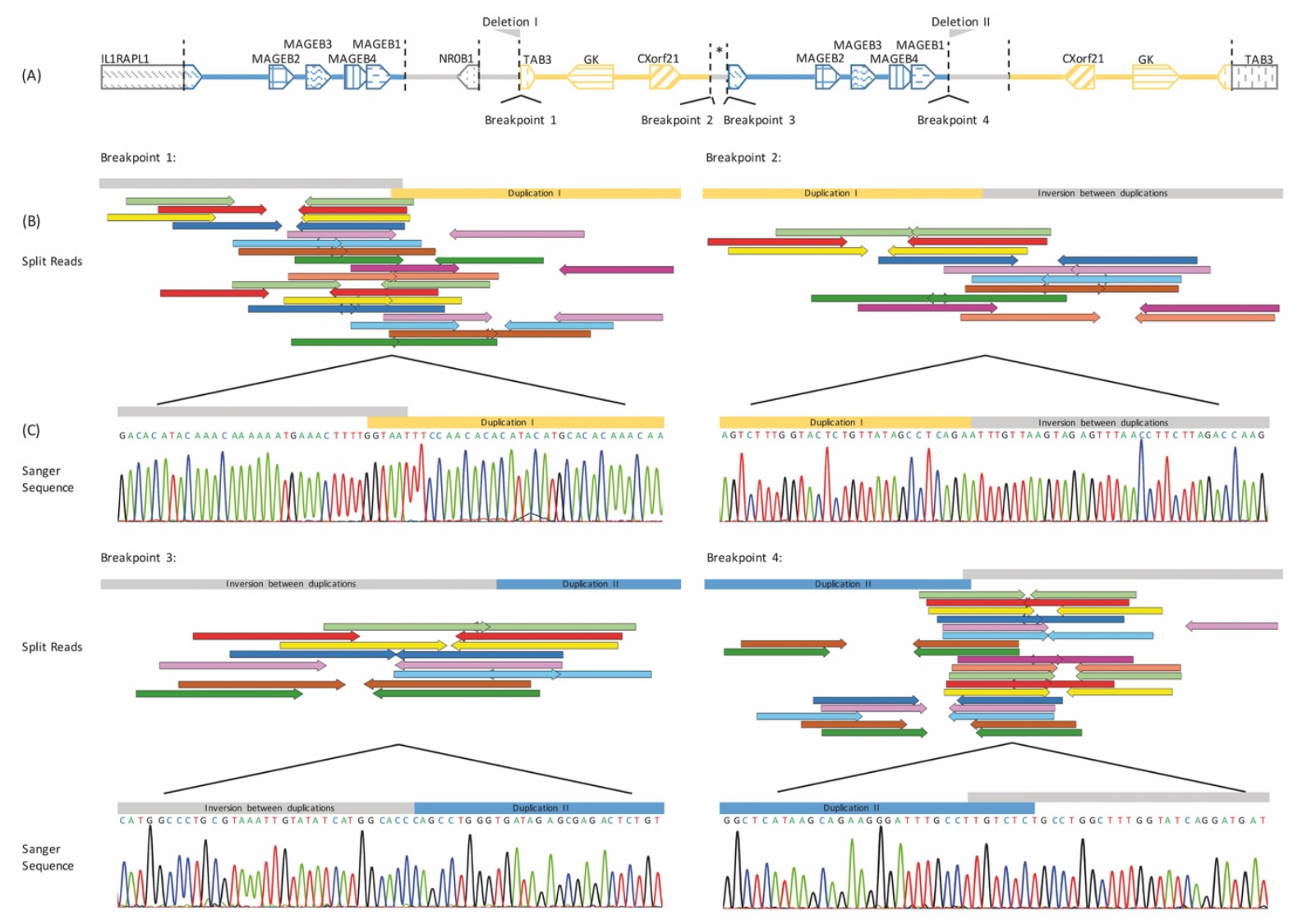

Figure 2. Structural Variation of Patient 2 (A) Overview of the structural variation upstream of the NROB1 gene. The genomic distances are not to scale. A $447 \mathrm{~kb}$ duplication of CXorf21, GK and part of TAB3 (yellow) originally mapping to $30,401,819-30,848,988$ is inserted in an inverted manner between breakpoint 1 (bp1; chrX:30,336,745) and bp2 (chrX: 30,340,605) $9.25 \mathrm{~kb}$ upstream of the $N R O B 1$ reading frame. ${ }^{*}$ marks a $1.2 \mathrm{~kb}$ piece of reference sequence inverted between bp2 and bp3 separating the two large duplications. Both duplications are flanked by deletions indicated by the grey flags denoted Deletion I \& II. A 389kb duplication of the MAGEB genes 1-4 and part of IL2RAPL2 (blue) originally mapping to chrX: $29,924,420$ 30,313,761 is inserted between breakpoint 3 (chrX: 30,339,452) and 4 (chrX: $30,342,785$ ) in the same orientation as its reference sequence. (B) Shows position of extracted and aligned WGS split reads crossing the four breakpoints. Split reads mapped at varying distances apart for each breakpoint. Each pair was separated by at least $>29 \mathrm{~kb}$. Sequences at either side of bp1 and bp4 showed homology, thus no exact definition of the breakpoint position was 
medRxiv preprint doi: https://doi.org/10.1101/2020.03.25.20041418; this version posted March 30, 2020. The copyright holder for this preprint (which was not certified by peer review) is the author/funder, who has granted medRxiv a license to display the preprint in All rights reserved. No reuse allowed without permission.

possible, as depicted by the overlap of the grey and yellow or blue bars. (C) Shows

verification of sequences deduced from WGS reads through Sanger sequencing. 


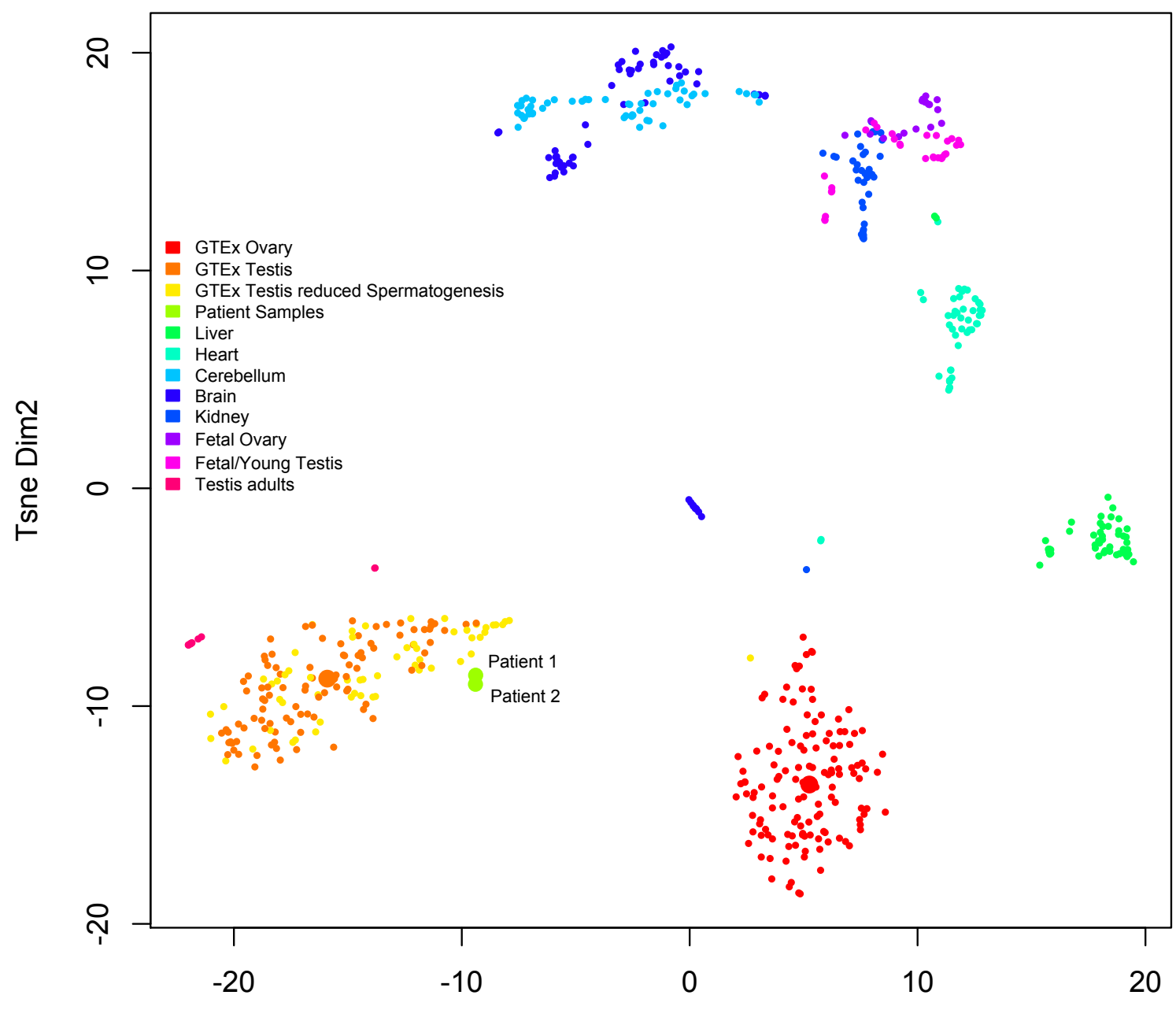

Tsne Dim1

Figure 3: Comparison of patient gonad transcriptomes to healthy tissues. The twodimensional t-SNE plot compares the transcriptomes of testis and ovary tissue from young and old healthy donors as well as from liver, heart, cerebellum, kidney and brain. The samples come from the GTEx database (red, orange, yellow points) as well as data set EMTAB-6814 from ArrayExpress. t-SNE was calculated for 608 samples using randomly 5000 out of 13,005 genes expressed in either patient sample. Testis samples are marked as either orange or yellow, depending on whether they are reported to have normal or reduced 
medRxiv preprint doi: https://doi.org/10.1101/2020.03.25.20041418; this version posted March 30, 2020. The copyright holder for this preprint (which was not certified by peer review) is the author/funder, who has granted medRxiv a license to display the preprint in All rights reserved. No reuse allowed without permission.

spermatogenesis. The large orange and red sports among the testis and ovary tissue group mark the t-SNE the median expression of all tissue samples.

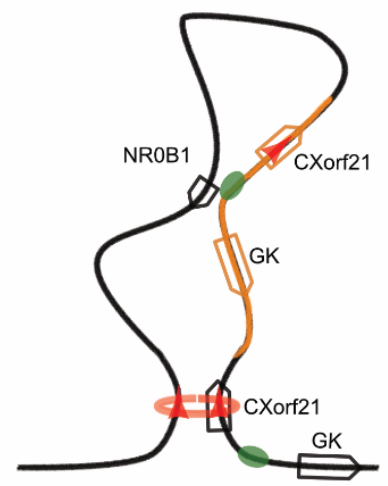

P1a

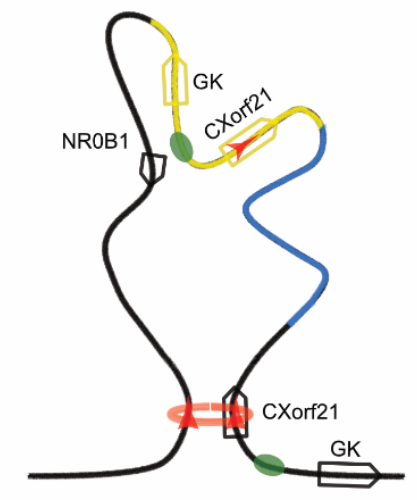

P2

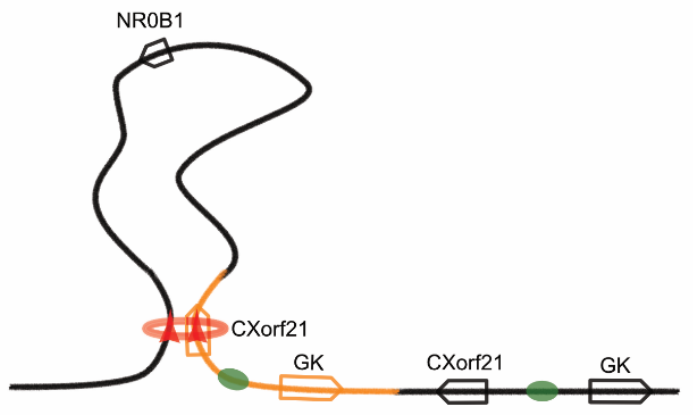

$\mathrm{P} 1 \mathrm{~b}$

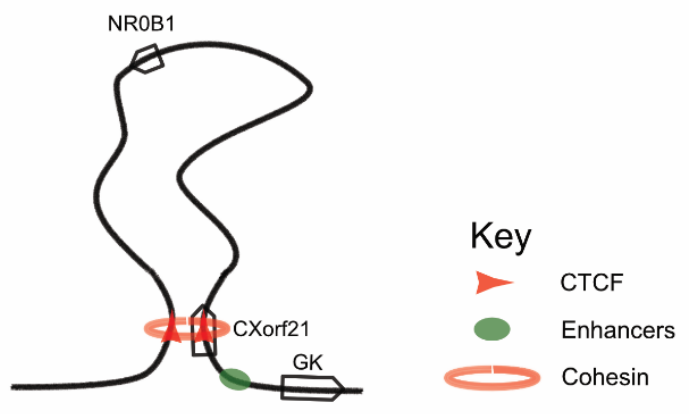

Normal

Figure 4: Schematic representation of topologically associating domain (TAD) in patients

with NROB1 upstream duplications. The NROB1 TAD is represented as curled loop. Regions inserted through duplication are illustrated by coloured string segments. Genes are depicted by arrows showing their respective direction of transcription and are equally coloured, if part of a duplication. When a TAD comprises both the NROB1 and the GK \& CXorf21 genes with their in-between enhancers (green oval) the NROB1 promoter can encounter the noncognate enhancer normally shielded away from the gene by position outside the TAD. P1a 
medRxiv preprint doi: https://doi.org/10.1101/2020.03.25.20041418; this version posted March 30, 2020. The copyright holder for this preprint (which was not certified by peer review) is the author/funder, who has granted medRxiv a license to display the preprint in All rights reserved. No reuse allowed without permission.

and $b$ depict alternate TAD conformations depending on location of commenced loop extrusion.

\section{References}

Ahmed, S. F., Khwaja, O., \& Hughes, I. A. (2000). The role of a clinical score in the assessment of ambiguous genitalia. BJU Int, 85(1), 120-124.

Athar, A., Fullgrabe, A., George, N., Iqbal, H., Huerta, L., Ali, A., . . Brazma, A. (2019). ArrayExpress update - from bulk to single-cell expression data. Nucleic Acids Res, 47(D1), D711-D715. doi:10.1093/nar/gky964

Audi, L., Ahmed, S. F., Krone, N., Cools, M., McElreavey, K., Holterhus, P. M., ... The, E. U. C. A. (2018). GENETICS IN ENDOCRINOLOGY: Approaches to molecular genetic diagnosis in the management of differences/disorders of sex development (DSD): position paper of EU COST Action BM 1303 'DSDnet'. Eur J Endocrinol, 179(4), R197-R206. doi:10.1530/EJE-18-0256

Baetens, D., Guran, T., Mendonca, B. B., Gomes, N. L., De Cauwer, L., Peelman, F., . . De Baere, E. (2018). Biallelic and monoallelic ESR2 variants associated with 46,XY disorders of sex development. Genet Med, 20(7), 717-727. doi:10.1038/gim.2017.163

Barbaro, M., Cicognani, A., Balsamo, A., Lofgren, A., Baldazzi, L., Wedell, A., \& Oscarson, M. (2008). Gene dosage imbalances in patients with $46, X Y$ gonadal DSD detected by an in-house-designed synthetic probe set for multiplex ligation-dependent probe amplification analysis. Clin Genet, 73(5), 453-464. doi:10.1111/j.13990004.2008.00980.x

Barbaro, M., Cook, J., Lagerstedt-Robinson, K., \& Wedell, A. (2012). Multigeneration Inheritance through Fertile XX Carriers of an NROB1 (DAX1) Locus Duplication in a Kindred of Females with Isolated XY Gonadal Dysgenesis. Int J Endocrinol, 2012, 504904. doi:10.1155/2012/504904

Barbaro, M., Oscarson, M., Schoumans, J., Staaf, J., Ivarsson, S. A., \& Wedell, A. (2007). Isolated $46, \mathrm{XY}$ gonadal dysgenesis in two sisters caused by a Xp21.2 interstitial duplication containing the DAX1 gene. J Clin Endocrinol Metab, 92(8), 3305-3313. doi:10.1210/jc.2007-0505

Bardoni, B., Zanaria, E., Guioli, S., Floridia, G., Worley, K. C., Tonini, G., . . . et al. (1994). A dosage sensitive locus at chromosome Xp21 is involved in male to female sex reversal. Nat Genet, 7(4), 497-501. doi:10.1038/ng0894-497

Bashamboo, A., Eozenou, C., Rojo, S., \& McElreavey, K. (2017). Anomalies in human sex determination provide unique insights into the complex genetic interactions of early gonad development. Clin Genet, 91(2), 143-156. doi:10.1111/cge.12932

Boulanger, L., Pannetier, M., Gall, L., Allais-Bonnet, A., Elzaiat, M., Le Bourhis, D., . . . Pailhoux, E. (2014). FOXL2 is a female sex-determining gene in the goat. Curr Biol, 24(4), 404-408. doi:10.1016/j.cub.2013.12.039

Bray, N. L., Pimentel, H., Melsted, P., \& Pachter, L. (2016). Near-optimal probabilistic RNAseq quantification. Nat Biotechnol, 34(5), 525-527. doi:10.1038/nbt.3519 
medRxiv preprint doi: https://doi.org/10.1101/2020.03.25.20041418; this version posted March 30, 2020. The copyright holder for this preprint (which was not certified by peer review) is the author/funder, who has granted medRxiv a license to display the preprint in

All rights reserved. No reuse allowed without permission.

Carithers, L. J., Ardlie, K., Barcus, M., Branton, P. A., Britton, A., Buia, S. A., . . Consortium, G. T. (2015). A Novel Approach to High-Quality Postmortem Tissue Procurement: The GTEx Project. Biopreserv Biobank, 13(5), 311-319. doi:10.1089/bio.2015.0032

Chaboissier, M. C., Kobayashi, A., Vidal, V. I., Lutzkendorf, S., van de Kant, H. J., Wegner, M., . .. Schedl, A. (2004). Functional analysis of Sox8 and Sox9 during sex determination in the mouse. Development, 131(9), 1891-1901. doi:10.1242/dev.01087

de Wit, E., Vos, E. S., Holwerda, S. J., Valdes-Quezada, C., Verstegen, M. J., Teunissen, H., . . . de Laat, W. (2015). CTCF Binding Polarity Determines Chromatin Looping. Mol Cell, 60(4), 676-684. doi:10.1016/j.molcel.2015.09.023

DePristo, M. A., Banks, E., Poplin, R., Garimella, K. V., Maguire, J. R., Hartl, C., . . Daly, M. J. (2011). A framework for variation discovery and genotyping using next-generation DNA sequencing data. Nat Genet, 43(5), 491-498. doi:10.1038/ng.806

Dixon, J. R., Selvaraj, S., Yue, F., Kim, A., Li, Y., Shen, Y., . . Ren, B. (2012). Topological domains in mammalian genomes identified by analysis of chromatin interactions. Nature, 485(7398), 376-380. doi:10.1038/nature11082

Dong, Y., Yi, Y., Yao, H., Yang, Z., Hu, H., Liu, J., . . Liang, Z. (2016). Targeted next-generation sequencing identification of mutations in patients with disorders of sex development. BMC Med Genet, 17, 23. doi:10.1186/s12881-016-0286-2

Franke, M., Ibrahim, D. M., Andrey, G., Schwarzer, W., Heinrich, V., Schopflin, R., . . . Mundlos, S. (2016). Formation of new chromatin domains determines pathogenicity of genomic duplications. Nature, 538(7624), 265-269. doi:10.1038/nature19800

Fudenberg, G., Imakaev, M., Lu, C., Goloborodko, A., Abdennur, N., \& Mirny, L. A. (2016). Formation of Chromosomal Domains by Loop Extrusion. Cell Rep, 15(9), 2038-2049. doi:10.1016/j.celrep.2016.04.085

Garcia-Acero, M., Molina, M., Moreno, O., Ramirez, A., Forero, C., Cespedes, C., ... Rojas, A. (2019). Gene dosage of DAX-1, determining in sexual differentiation: duplication of DAX-1 in two sisters with gonadal dysgenesis. Mol Biol Rep. doi:10.1007/s11033-01904758-y

Giangrande, P. H., Zhu, W., Schlisio, S., Sun, X., Mori, S., Gaubatz, S., \& Nevins, J. R. (2004). A role for E2F6 in distinguishing G1/S- and G2/M-specific transcription. Genes Dev, 18(23), 2941-2951. doi:10.1101/gad.1239304

Goloborodko, A., Marko, J. F., \& Mirny, L. A. (2016). Chromosome Compaction by Active Loop Extrusion. Biophys J, 110(10), 2162-2168. doi:10.1016/j.bpj.2016.02.041

Gomez-Marin, C., Tena, J. J., Acemel, R. D., Lopez-Mayorga, M., Naranjo, S., de la CalleMustienes, E., ... Gomez-Skarmeta, J. L. (2015). Evolutionary comparison reveals that diverging CTCF sites are signatures of ancestral topological associating domains borders. Proc Natl Acad Sci U S A, 112(24), 7542-7547. doi:10.1073/pnas.1505463112

Guo, Y., Xu, Q., Canzio, D., Shou, J., Li, J., Gorkin, D. U., . . Wu, Q. (2015). CRISPR Inversion of CTCF Sites Alters Genome Topology and Enhancer/Promoter Function. Cell, 162(4), 900-910. doi:10.1016/j.cell.2015.07.038

Hanzelmann, S., Castelo, R., \& Guinney, J. (2013). GSVA: gene set variation analysis for microarray and RNA-seq data. BMC Bioinformatics, 14, 7. doi:10.1186/1471-2105-147

Hnisz, D., Weintraub, A. S., Day, D. S., Valton, A. L., Bak, R. O., Li, C. H., . . Young, R. A. (2016). Activation of proto-oncogenes by disruption of chromosome neighborhoods. Science, 351(6280), 1454-1458. doi:10.1126/science.aad9024

Horvath, G. C., Kistler, W. S., \& Kistler, M. K. (2004). RFX2 is a potential transcriptional regulatory factor for histone $\mathrm{H} 1 \mathrm{t}$ and other genes expressed during the meiotic phase 
medRxiv preprint doi: https://doi.org/10.1101/2020.03.25.20041418; this version posted March 30, 2020. The copyright holder for this preprint (which was not certified by peer review) is the author/funder, who has granted medRxiv a license to display the preprint in

All rights reserved. No reuse allowed without permission.

of spermatogenesis. Biol Reprod, 71(5), 1551-1559.

doi:10.1095/biolreprod.104.032268

Hurlin, P. J. (2013). Control of vertebrate development by MYC. Cold Spring Harb Perspect Med, 3(9), a014332. doi:10.1101/cshperspect.a014332

Ibn-Salem, J., Kohler, S., Love, M. I., Chung, H. R., Huang, N., Hurles, M. E., . . . Robinson, P. N. (2014). Deletions of chromosomal regulatory boundaries are associated with congenital disease. Genome Biol, 15(9), 423. doi:10.1186/s13059-014-0423-1

Kistler, W. S., Baas, D., Lemeille, S., Paschaki, M., Seguin-Estevez, Q., Barras, E., . . Reith, W. (2015). RFX2 Is a Major Transcriptional Regulator of Spermiogenesis. PLoS Genet, 11(7), e1005368. doi:10.1371/journal.pgen.1005368

Krijthe, J. (2015). Rtsne: T-Distributed Stochastic Neighbor Embedding using a Barnes-Hut Implementation. https://github.com/jkrijthe/Rtsne.

Kulle, A. E., Riepe, F. G., Melchior, D., Hiort, O., \& Holterhus, P. M. (2010). A novel ultrapressure liquid chromatography tandem mass spectrometry method for the simultaneous determination of androstenedione, testosterone, and dihydrotestosterone in pediatric blood samples: age- and sex-specific reference data. J Clin Endocrinol Metab, 95(5), 2399-2409.

Ledig, S., Hiort, O., Scherer, G., Hoffmann, M., Wolff, G., Morlot, S., . . Wieacker, P. (2010). Array-CGH analysis in patients with syndromic and non-syndromic $X Y$ gonadal dysgenesis: evaluation of array CGH as diagnostic tool and search for new candidate loci. Hum Reprod, 25(10), 2637-2646. doi:10.1093/humrep/deq167

Ledig, S., Hiort, O., Wunsch, L., \& Wieacker, P. (2012). Partial deletion of DMRT1 causes 46,XY ovotesticular disorder of sexual development. Eur J Endocrinol, 167(1), 119124. doi:10.1530/EJE-12-0136

Lek, M., Karczewski, K. J., Minikel, E. V., Samocha, K. E., Banks, E., Fennell, T., . . Exome Aggregation, C. (2016). Analysis of protein-coding genetic variation in 60,706 humans. Nature, 536(7616), 285-291. doi:10.1038/nature19057

Lettice, L. A., Daniels, S., Sweeney, E., Venkataraman, S., Devenney, P. S., Gautier, P., . . FitzPatrick, D. R. (2011). Enhancer-adoption as a mechanism of human developmental disease. Hum Mutat, 32(12), 1492-1499. doi:10.1002/humu.21615

Li, H., \& Durbin, R. (2009). Fast and accurate short read alignment with Burrows-Wheeler transform. Bioinformatics, 25(14), 1754-1760. doi:10.1093/bioinformatics/btp324

Liberzon, A., Birger, C., Thorvaldsdottir, H., Ghandi, M., Mesirov, J. P., \& Tamayo, P. (2015). The Molecular Signatures Database (MSigDB) hallmark gene set collection. Cell Syst, 1(6), 417-425. doi:10.1016/j.cels.2015.12.004

Ludbrook, L. M., Bernard, P., Bagheri-Fam, S., Ryan, J., Sekido, R., Wilhelm, D., . . . Harley, V. R. (2012). Excess DAX1 leads to XY ovotesticular disorder of sex development (DSD) in mice by inhibiting steroidogenic factor-1 (SF1) activation of the testis enhancer of SRY-box-9 (Sox9). Endocrinology, 153(4), 1948-1958. doi:10.1210/en.2011-1428

Lupianez, D. G., Kraft, K., Heinrich, V., Krawitz, P., Brancati, F., Klopocki, E., . . Mundlos, S. (2015). Disruptions of topological chromatin domains cause pathogenic rewiring of gene-enhancer interactions. Cell, 161(5), 1012-1025. doi:10.1016/j.cell.2015.04.004

Lupianez, D. G., Spielmann, M., \& Mundlos, S. (2016). Breaking TADs: How Alterations of Chromatin Domains Result in Disease. Trends Genet, 32(4), 225-237. doi:10.1016/j.tig.2016.01.003

Matson, C. K., Murphy, M. W., Sarver, A. L., Griswold, M. D., Bardwell, V. J., \& Zarkower, D. (2011). DMRT1 prevents female reprogramming in the postnatal mammalian testis. Nature, 476(7358), 101-104. doi:10.1038/nature10239 
medRxiv preprint doi: https://doi.org/10.1101/2020.03.25.20041418; this version posted March 30, 2020. The copyright holder for this preprint (which was not certified by peer review) is the author/funder, who has granted medRxiv a license to display the preprint in

All rights reserved. No reuse allowed without permission.

Meinel, J., Dwivedi, G., Holterhus, P. M., Hiort, O., \& Werner, R. (2019). qPCR screening for Xp21.2 copy number variations in patients with elusive aetiology of $46, X Y$ DSD. Horm Res Paediatr, 91((suppl 1)), 98. doi:DOI: 10.1159/000501868

Narendra, V., Rocha, P. P., An, D., Raviram, R., Skok, J. A., Mazzoni, E. O., \& Reinberg, D. (2015). CTCF establishes discrete functional chromatin domains at the Hox clusters during differentiation. Science, 347(6225), 1017-1021. doi:10.1126/science.1262088

Nora, E. P., Lajoie, B. R., Schulz, E. G., Giorgetti, L., Okamoto, I., Servant, N., . . Heard, E. (2012). Spatial partitioning of the regulatory landscape of the $\mathrm{X}$-inactivation centre. Nature, 485(7398), 381-385. doi:10.1038/nature11049

Rao, S. S. P., Huang, S. C., Glenn St Hilaire, B., Engreitz, J. M., Perez, E. M., Kieffer-Kwon, K. R., ... Aiden, E. L. (2017). Cohesin Loss Eliminates All Loop Domains. Cell, 171(2), 305320 e324. doi:10.1016/j.cell.2017.09.026

Rausch, T., Zichner, T., Schlattl, A., Stutz, A. M., Benes, V., \& Korbel, J. O. (2012). DELLY: structural variant discovery by integrated paired-end and split-read analysis. Bioinformatics, 28(18), i333-i339. doi:10.1093/bioinformatics/bts378

Ritchie, M. E., Phipson, B., Wu, D., Hu, Y., Law, C. W., Shi, W., \& Smyth, G. K. (2015). limma powers differential expression analyses for RNA-sequencing and microarray studies. Nucleic Acids Res, 43(7), e47. doi:10.1093/nar/gkv007

Sanborn, A. L., Rao, S. S., Huang, S. C., Durand, N. C., Huntley, M. H., Jewett, A. I., . . Aiden, E. L. (2015). Chromatin extrusion explains key features of loop and domain formation in wild-type and engineered genomes. Proc Natl Acad Sci U S A, 112(47), E6456-6465. doi:10.1073/pnas.1518552112

Schacht, T., Oswald, M., Eils, R., Eichmuller, S., \& Konig, R. (2014). Estimating the activity of transcription factors by the effect on their target genes. Bioinformatics(30(17):i4017).

Smyk, M., Berg, J. S., Pursley, A., Curtis, F. K., Fernandez, B. A., Bien-Willner, G. A., . . . Stankiewicz, P. (2007). Male-to-female sex reversal associated with an approximately $250 \mathrm{~kb}$ deletion upstream of NROB1 (DAX1). Hum Genet, 122(1), 63-70. doi:10.1007/s00439-007-0373-8

Soneson, C., Love, M. I., \& Robinson, M. D. (2015). Differential analyses for RNA-seq: transcript-level estimates improve gene-level inferences. F1000Res, 4, 1521. doi:10.12688/f1000research.7563.2

Swain, A., Narvaez, V., Burgoyne, P., Camerino, G., \& Lovell-Badge, R. (1998). Dax1 antagonizes Sry action in mammalian sex determination. Nature, 391(6669), 761-767. doi:10.1038/35799

Swain, A., Zanaria, E., Hacker, A., Lovell-Badge, R., \& Camerino, G. (1996). Mouse Dax1 expression is consistent with a role in sex determination as well as in adrenal and hypothalamus function. Nat Genet, 12(4), 404-409. doi:10.1038/ng0496-404

Szabo, Q., Bantignies, F., \& Cavalli, G. (2019). Principles of genome folding into topologically associating domains. Sci Adv, 5(4), eaaw1668. doi:10.1126/sciadv.aaw1668

Uhlenhaut, N. H., Jakob, S., Anlag, K., Eisenberger, T., Sekido, R., Kress, J., . . . Treier, M. (2009). Somatic sex reprogramming of adult ovaries to testes by FOXL2 ablation. Cell, 139(6), 1130-1142. doi:10.1016/j.cell.2009.11.021

van der Maaten, L. (2014). Accelerating t-SNE using Tree-Based Algorithms. J Mach Learn $\operatorname{Res}(15: 3221-3245)$.

Vietri Rudan, M., Barrington, C., Henderson, S., Ernst, C., Odom, D. T., Tanay, A., \& Hadjur, S. (2015). Comparative $\mathrm{Hi}-\mathrm{C}$ reveals that CTCF underlies evolution of chromosomal domain architecture. Cell Rep, 10(8), 1297-1309. doi:10.1016/j.celrep.2015.02.004 
medRxiv preprint doi: https://doi.org/10.1101/2020.03.25.20041418; this version posted March 30, 2020. The copyright holder for this preprint (which was not certified by peer review) is the author/funder, who has granted medRxiv a license to display the preprint in All rights reserved. No reuse allowed without permission.

Wang, K., Li, M., \& Hakonarson, H. (2010). ANNOVAR: functional annotation of genetic variants from high-throughput sequencing data. Nucleic Acids Res, 38(16), e164. doi:10.1093/nar/gkq603

Wang, Y., Song, F., Zhang, B., Zhang, L., Xu, J., Kuang, D., . . Yue, F. (2018). The 3D Genome Browser: a web-based browser for visualizing 3D genome organization and longrange chromatin interactions. Genome Biol, 19(1), 151. doi:10.1186/s13059-0181519-9

Weischenfeldt, J., Dubash, T., Drainas, A. P., Mardin, B. R., Chen, Y., Stutz, A. M., . . Korbel, J. O. (2017). Pan-cancer analysis of somatic copy-number alterations implicates IRS4 and IGF2 in enhancer hijacking. Nat Genet, 49(1), 65-74. doi:10.1038/ng.3722

White, S., Ohnesorg, T., Notini, A., Roeszler, K., Hewitt, J., Daggag, H., . . Sinclair, A. (2011). Copy number variation in patients with disorders of sex development due to $46, \mathrm{XY}$ gonadal dysgenesis. PLoS One, 6(3), e17793. doi:10.1371/journal.pone.0017793

Yu, R. N., Ito, M., Saunders, T. L., Camper, S. A., \& Jameson, J. L. (1998). Role of Ahch in gonadal development and gametogenesis. Nat Genet, 20(4), 353-357.

doi:10.1038/3822 